\title{
The Application of "Practical Training Teaching Project" in the Teaching of Art Design
}

\author{
Zhang Shu, Liu Yijie \\ Department of Art \& Design, Wuhan University of Science and Technology, Wuhan City, Hubei Province, China \\ Dc5349@126.com, 308864991@qq.com
}

\begin{abstract}
Practical training teaching project is to make students to conduct practical operational ability based on the particularity and professional characteristics of the design courses. At first, this paper introduces the significance of practical training teaching project, then puts forward the feasibility of practical training teaching project in class and after school based on the traditional teaching methods, and conducts the teaching analysis through case study on specific courses at last in order to promote the practical ability and innovation of practical training teaching project.
\end{abstract}

Index Terms - Art Design, Practical training teaching project, The practical and innovation of practical

\section{Introduction}

Unlike other education disciplines, art design teaching can adopt the structured and systemic teaching combined with tutoring with its own uniqueness and innovation. As more and more academies emphasize their art's characteristics and teaching quality, practical training teaching project has begun to be adopted in design courses.

Practical training teaching is an effective teaching model upon practical ability and innovation ability. It is to digest and consolidate the theoretical knowledge learned in the process of hands-on operational practice, which should reflect on the characteristics of the practical teaching. As for students of art design major, professional basic theoretical knowledge is important, but the practical ability and hands-on operational ability is more important, which are an important indicator of the professional level in the inspection. So strengthening and improving students' hands-on operational ability and practical ability needs to start from the classroom by means of practical training operations gradually deepening into the practical ability of students through changing existing single teaching form and teaching method in order to make the students better understanding the mutual integration of theoretical knowledge and social comprehensive abilities.

\section{The Significance of Practical Training Teaching project}

\section{A. In the View of Subject Specialty}

The art design is a really specific discipline in the institutions of higher education. The teaching of the discipline requires that teachers and students are able to keenly seize all aspects of information including social, cultural and economic information at present, and make the information to reflect on the design works through visual symbols.

\section{B. In the View of Innovation Practice}

The practical training project with a combination of teaching can exercise not only the students' hands-on operational ability, but also the use of the comprehensive theoretical knowledge. It systematically solves the process of thinking-exploration-solving-summary encountered in teaching program, which helps improve students' operational ability and innovation ability in the thinking, design, production and other aspects.

\section{In the View of Teaching Effect}

Team of teachers, as teachers from colleges and universities teaching for many years, have a wealth of teaching cases and professional knowledge background. The continually adjusting curriculum system in the comprehensive teaching with theory and practical is more suitable for the needs of teaching methods in the field. The material, teaching works and teaching effect in the practical training the students obtained can be regard as teaching outcomes of teaching team in the future, which can not only enrich the teacher's teaching, but also set a good example for students in the lower grades so that form a good teaching effect.

\section{The Two Feasibility of Practical Training Teaching project}

Training courses of art design can not simply be defined as projects or case teaching pedagogy. They can be divided into in class and after school in terms of teaching places. Based on different training contents, they can be divided into virtual projects and practical social projects. These factors can completely compensate teaching deficiencies in the traditional way, so that constitutes a more complete and complex teaching classroom of art design major.

\section{A. Practical Training Teaching project in Class}

Practical training teaching project in class can be used in many art design courses, which is a very strong practical teaching method. It is very helpful for students to examine experience, practice and summarize in class. This intuitive and strong practical learning method helps students to cultivate the thinking ability, the ability to analyze problems and teamwork. Taken "folk art" course as an example, the implementation of practical training teaching project in class will be explored as follows.

"Folk Art" course is a very strong practical course, which has been set up in many design colleges in China. But the course in most colleges is classified into purely theoretical courses. After teachers introduce a large number of the types, features and production process of folk art in the classroom, the students have a basic understanding of it. Teachers in minority colleges with the hands-on operational ability will arrange a hands-on assignment in the course, such as a paper- 
cutting operation. This method has the hands-on operational part, but the purpose of the project is relatively weak. It should be closely linked with the operation of the market system from the design, technology, materials and color of folk art. Practitioners teachers with practical experience, provides a healthy design market class for their professional teaching based on the perfect and standardized design market system. Teachers adopting this method had better contact with a specific design unit, select a completed design order and assign a task to students based on the specific needs of customers. To be specific, teachers require students to finish the task based on the contents of the social inspection, the thinking problems, the range of data collecting and the specific design requirements of the project, which is regard the social requirements as the standard for evaluation. Students can expand their understanding of the content through group discussions based on their pre-assignment tasks, then add their own design ideas into the comprehensive process with traditional patterns and modern designs, which fully expresses the design theme, color scheme, material selection, process performance and so on. It is great beneficial for practical training teaching project in class to supplement the current classroom pattern and enhance students' application ability

\section{B. Practical Training Teaching project after university}

Practical training teaching project after university is also a very strong practical teaching method. Taken social standards as the guide, it has higher levels of requirements in the communication, modification, program identification and late marketing for the specific project. This project can avoid some shortcomings of the university environment, such as the limited class hours, the lack of university hardware equipments, limited faculty and other issues. Taken "commercial illustration" course and "urban design" course as an example, the implementation of practical training teaching project after university will be explored as follows.

Except hand-drawn illustrations, there are many hands-on operational contents in "Commercial illustration" course, for example, the current emerging CG illustration is indispensable and essential. In order to achieve the professional standards and requirements, and to achieve better results, the teacher can arrange eight hours to pay site visits to some animation company, visiting the department of two-dimensional and three-dimensional animation groups after hand-drawn illustrations course and assignments are completed. The purpose of visiting is to understand the conversion and the actual production process of hand-drawn drawings and computer illustrations. The teacher can directly arrange students to participate in an ongoing project of the animation company, invite the design director within the company to lecture the project alternatives and customer requirements, etc., and then introduce w new knowledge, new technology and new techniques into the practical training teaching after university. Such co-teaching in and after university can better improve students' professionalism, design levels and comprehensive application ability.

Combining the "urban design" course and the Practical Training Teaching Project after university about the survey and analysis part of city color.The method is detailed as follows:

a) Survey

Surveys are carried out in a larger scope of urban environment considering all aspects including cityscapes and urban features by recording the state of buildings, grounds, artificial facilities, surrounding plantations, religious beliefs, etc. in the urban environment through a camera and a whiteboard, and document relevant data by using of a color card.

\section{b) Analysis}

Collate all data collected and find the hue groups of planar color blocks that match the color card data, and use it as an extended range for color database. Hue groups depends upon the matching of dominant color, embellishment color and surrounding colors. Only if they are homogeneous, heterogeneous or complementary can they form harmonious and effective color plans.

c) Design

Based on early-stage surveys color design is carried out considering surrounding environment and historical and cultural influences. In the process of design, it will be very hard to achieve ideal color effect if purely matching colors by means of combination arrangement. We have to break the traditional color matching stereotype that long existing in people's mind and see it from the angle of plane constitution, e.g. Contrasting colors, green and red, can form a very unique color space if we match them carefully with attention paid to harmony. For example, the colors of lighting from office buildings in downtown Shanghai actually adopt a dynamic color changing system, which demonstrates from the perspective of variability and vitality that colors come from humanized concepts.

d) Approval

As soon as the urban environment color design and application plan is finalized, it will be submitted to design, planning and management departments for review and approval, after which it will be handed to the construction unit for communication of details. During construction at later stages, the designer should walk down regularly on the site to provide guidance for construction to ensure the overall uniformity of the color of the urban environment.

\section{Conclusion}

To sum up, the practical training teaching project is not only a teaching method worth exploring all the time, but also the breakthrough of quality-oriented education in training practical ability and innovative spirit as the focus. As mastering the teaching knowledge in class, combining with the practice, applying to the actual design project and fully understanding the society, market, customers' needs, the art design teaching can embark on a new way to give full play the enthusiasm and initiative of teachers and students, and thus cultivate a true art design talent with innovative spirit and practical application ability so as to meet the needs of today's art design market and the demand for art design talent. 


\section{References}

[1] Suo Xinyu, "The exploration of art design teaching of non material cultural heritage context," Education Forum, 2013(17).

[2] Kuang Tingshun, Exploration of "practical teaching psychology of advertising", The Science Education Article Collects, 2010(4).

[3] Xia Ningning, Exploration of practical teaching of advertising visual design, Popular Literature, 2013(6).
[4] Wang Hongbing, The practice of classroom teaching going into the studio (enterprise) teaching. HuaZhang. 2012 (35)

[5] Wang Jiancai, Constitution art and design field investigation teaching and extracurricular training teaching, Journal of Chuxiong Normal University. $2010.25(4)$

[6] Zhang Shu, Application of Practical Training Teaching Project in the teaching of design psychology. Eastern Youth.2013(11) 